\title{
The influence of inventory sequencing for the improvement of inventory control: Evidence from a South African automotive assembly organisation
}

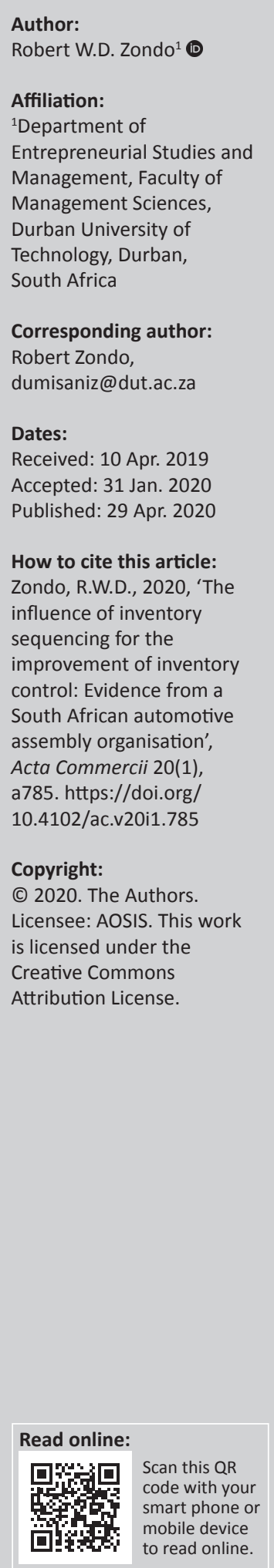

Orientation: Control of inventory is a central issue in operations management and has received a considerable amount of attention in literatures. One of the reasons behind this attention is that inventory holding comprises a significant cost in the supply chain.

Research purpose: The study investigates whether the inventory sequencing system has an influence in improving inventory control in an automotive assembly organisation in KwaZuluNatal, South Africa.

Motivation for the study: There is a lack of coordination and control in the management of the inventory in the supply chain in South Africa. The traditional supply chain practice uses sequences of weakly connected activities both within and outside the organisation. This leads to misalignments in the supply chain.

Research design, approach and methods: The automotive company that has adopted an inventory sequencing strategy participated in the study. The collection of data was carried out in two phases. This includes the collection of pre- and post-inventory sequencing results from company records for production volumes, inventory costs and product damages. The preinventory sequencing results were quarterly data reflecting the company's performance over the 4-year period prior to the implementation of inventory sequencing. The study was quantitative in design and examined the production and related experiences of the automotive assembly organisation that has adopted an inventory sequencing procedure. The Ordinary Least Squares (OLS) model, using the Statistical Package for Social Sciences (SPSS) was used to analyse data. The company operates in the eThekwini District Municipality in KwaZulu-Natal.

Main findings: The study established that the inventory sequencing has no influence on either the production volumes or inventory costs. However, it has the ability to reduce product damages.

Practical/managerial implications: The automotive sector should revise their operations and develop inventory control strategies, policies and practices that help to achieve new business goals.

Contribution/value-add: The original value of this article is its approach in uncovering strengths and weaknesses of inventory sequencing for the improvement of inventory control in the automotive sector.

Keywords: automotive assembly organisation; inventory control; inventory costs; KwaZuluNatal; product damages; production volumes.

\section{Introduction}

It is noted that the majority of applied inventory control methods are based on models, assuming that demand has a normal probability distribution (De Leeuw, Holweg \& Williams 2011). With the exception of items with a high degree of demand, this is usually a reasonable assumption, especially under conditions of long lead times. This is a result of the central limit theorem, which states that when many independent random variables are summed, no matter what their underlying probability distributions are like, the resulting random variable will approach the normal distribution (Uddin, Soto \& Lastra 2010). A long lead time means a greater number of daily demand observations and, consequently, a greater number of random variables to summarise to a total lead time demand. Accordingly, the longer the lead time, the better the normal distribution holds as an approximation of the real lead time demand distribution.

Other than the above-stated assumptions, the inventory management theory is concerned with defining minimal inventory levels given certain exogenous variables such as supply and delivery 
lead times, supply and demand uncertainty, batch sizes and product variety (Rumyantsev \& Netessine 2007). However, these theories often do not fully reflect business reality. Dubelaar, Chow and Larson (2001), for example, found that inventory in fashion supply chains is not related to demand uncertainty, a key component of inventory management theory. The complexities of supply chains encountered in practice, caused by aspects such as competitive behaviour, localised decision-making, incentives or business cycles, are largely ignored in most traditional models. Hence, this study focuses on the influence of inventory sequencing for the improvement of inventory control in the automotive assembly division. Gupta, Vanajakumari and Sriskandarajah (2017) define inventory sequencing as a specialised strategy to achieve justin-time (JIT). The process concept of JIT sees buffer at the production line as waste in capital bound. The aim is to eliminate buffers as much as possible at the expense of stability when disturbances arise. Kiff (2011) indicates that inventory sequencing is one of the most extreme applications where components arrive JIT and sequenced accordingly for consumption. The sequencing allows organisations to eliminate supply buffer as soon as the quantity of the component part buffer is reduced to a minimum. Gupta et al. (2017) emphasise that if the inventory is not sequenced according to a scheduled variety of production, all required components must be stocked in buffers.

Most inventory-related studies (Bowerson, Closs \& Cooper 2015; Frazelle 2016; Lee \& Billington 2014) focus on manufacturing and procurement-related processes upstream of the original equipment manufacturer (OEM), while little attention has been paid to inventory sequencing (Cachon \& Olivares 2010; Rishi 2010). This study focuses on the empirical assessment of inventory sequencing in the automotive industry. The capital-intensive nature of the industry with rapid changes in preferences and modifications resulting in obsolete inventory, and price decline for products as they are replaced by newer and more appealing models, increases the likelihood and frequency of inventory write-down for first in first out (FIFO) organisations (Rishi 2010). The inventory administration in the automotive industry is to hold inventory at the lowest potential charge, given the objective to guarantee continual provisions for continuing operations (Gupta et al. 2017). Inventory management ensures the availability of materials in sufficient amount as and when needed. Hence, Drucker (1946) referred to the automotive industry as 'the industry of industries' because of its share in total manufacturing employment, gross domestic product (GDP) and export, as well as its numerous forward and backward linkages with the rest of the economy. The prevalent massproduction thinking, introduced by Henry Ford at the start of the last century, changed the face of the industry and still shapes it today (Gupta et al. 2017). This was possible through the use of a more efficient assembly line technique that allowed the production of an automobile that could be manufactured and sold at a reasonable cost. Despite the improvements made through the proliferation of JIT or lean production paradigm (Monden 1983; Schonberger 1982; Womack, Jones \& Roos 2012), the vehicle distribution and dealer sales sourcing strategies have hardly changed in the automotive industry. The majority of vehicles across global regions are still made to forecast rather than end customer orders and subsequently sold from dealer inventory (Holweg \& Pil 2014). Dealer inventories in the automotive industry typically range between 20 and 100 days, dependent on the country (Holweg \& Pil 2014; Kiff 2011). At the higher levels of stock, ageing risks and the necessity for large discounts to avoid obsolescence vary significantly, given the fact that product variety is considerable (product variety may vary anywhere between a few hundred to tens of millions of different vehicle specifications for one type of car (Kiff 2011). Much of the studies in the automotive industry have been devoted to manufacturing performance, in particular labour productivity in the assembly plant (Frazelle 2016; Gupta et al. 2017; MacDuffie, Sethuraman \& Fisher 2009; Womack et al. 2012) and to the link between vehicle manufacturer and its component suppliers (Helper \& Sako 2009; Liker \& Wu 2000). Despite the efficiency of the manufacturing operation, the overall vehicle supply systems show poor performance in responding to customer needs (Holweg \& Pil 2014) and increasingly rely on incentives and rebates to sell their products. Such 'make-to-stock' policy aims at keeping the capacity utilisation at the vehicle assembly plant stable and high (Bowerson et al. 2015; Raturi et al. 2011).

In a capital-intensive industry, this approach makes manufacturers less vulnerable to swings in demand in the marketplace. Yet, given the current overcapacity and the increasing levels of customisation of the product (Holweg \& Pil 2014), such policy comes at the obvious penalty of large inventories in the marketplace. Despite the rising prominence of JIT manufacturing and logistics concepts in academia and industry from the 1990s onwards, several empirical studies have been unable to identify any significant decrease in the inventory levels of goods in many different industries, while work-in-progress (WIP) inventory and raw materials stocks have consistently decreased over time (Chen, Frank \& Wu 2005; Frazelle 2016; Hendricks \& Singhal 2008; Rishi 2010).

The inventory control in the supply chain is one of the major challenges in business. A traditional supply chain, all too often, is a sequence of weakly connected activities both within and outside the organisation and leads to many misalignments (Holweg \& Pil 2014). Resolving this inherent lack of coordination and control is a major value creation opportunity for supply chain managers. However, organisational barriers and restricted information flows often exist so that the complete centralised control of material flows is neither feasible nor desirable (Lee \& Billington 2014). Hence, this study investigates whether the inventory sequencing has the ability to improve inventory control in the selected automotive organisation in KwaZulu-Natal, South Africa.

\section{Literature review}

This section presents an overview of inventory sequencing, the essence of inventory control, as well as inventory management and control. 


\section{Overview of inventory sequencing}

The purpose of inventory is to provide enough products in order to meet customer demand (Frazelle 2016). Thus, inventory availability is the most important aspect of customer service. Consequently, Lee and Billington (2014) commend inventory sequencing as a complete fit in sequence with variation of assembly production. It is a selection of material to be used in a number of facilities aimed at reducing the production cost. It is perceived by management scientists as the process of production management that involves assigning inventory to workstations for a specified time period (Frazelle 2016). Bowerson et al. (2015) indicate that different inventory sequencing methods result in different job sequences, leading to different waiting times for individual jobs. However, inventory sequencing maximises efficiency and free flow of the production at minimum cost and time. It is just one specialised strategy to achieve JIT (Rishi 2010). Inventory sequencing is typically implemented only after the organisation has achieved a high degree of competency in JIT processes. Hence, the first step for the organisation is to implement JIT processes to synchronise all manufacturing and material departments inside the plant and thus collaborate with suppliers, customers and sub-contractors to reduce inventory buffers to within a few hours (Kiff 2011). This enables the inventory sequencing of processes to uncover deep manufacturing and logistics problems that are not easy to overcome. Sequencing refers to the order in which things happen or tasks are scheduled (Holweg \& Phil 2014). It is a selection of inventory for a series of jobs to be done on a number of service facilities. In inventory sequencing, a systematic procedure is adopted in assigning priorities to jobs, thereby determining the sequence in which jobs will be processed (Rishi 2010). Consequently, this study investigates the influence of the inventory sequencing method for the improvement of inventory control. Consequently, the next section discusses the essence of inventory control.

\section{The essence of inventory control}

Inventory is a complete directory that provides sufficient products in order to meet customer demand levels (Frazelle 2016). Hence, inventory management ensures that service commitments for customers are met (Bowerson et al. 2015). The reason that inventory is considered as waste is because it ties up capital and has a negative impact on cash flow (Mattsson 2007). Besides, companies typically spend heavily on inventory management. Inventory can also be damaged or become obsolete because of problems such as equipment downtime, long set-up times, lack of quality, lack of supplier reliability and so on. These problems are concealed by inventory, just like water covering rocks that lie on the sea bed, letting ships sail (Uddin et al. 2010). Inventory may be a short-term solution in the manufacturing process but not a permanent one because the problems are not really solved. De Leeuw et al. (2011) mention that the term 'zero inventory' was coined by one of the first Western authors to describe JIT. After the appearance of the zero inventory paradigm, researchers focused on inventories in Japanese companies that examined the differences between lean and traditional companies, as well as the relationship between inventories and performance. They achieved mixed empirical results. In fact, firms applying lean practices in manufacturing keep lower inventories and have higher inventory turnover than traditional companies do (Demeter \& Matyusz 2011; Rishi 2010). However, most Japanese companies have low inventories but not 'zero inventories' (De Leeuw et al. 2011). The eventual conclusion is that 'zero inventory' will not be achieved (Grünwald \& Fortuin 2013). Hence, JIT is an approach of continuous and forced problem-solving that focuses on throughput and reduced inventory (Heizer \& Render 2011). In this latter sense of continuous improvement, some studies recommend reducing lot sizes (Frazelle 2016; Karlsson \& Ahlström 1996; Martínez-Sánchez \& Pérez-Pérez 2001). Process improvement techniques contribute to the reduction of inventories, making the product 'flow' through the process, thus reducing manufacturing lead time (Lee-Mortimer 2006). Work-in-progress and lead time reductions are identified as benefits of implementing JIT (De Leeuw et al. 2011). As a consequence, some studies propose WIP and manufacturing lead time or total product cycle time as measures for tracking progress (Bhasin 2008; Martínez-Sánchez \& Pérez-Pérez 2001; Motwani 2003). However, as these studies are based on surveys or experiences of companies, none of them go deeply into the quantitative relationships amongst WIP, manufacturing lead time or other parameters of the process (De Leeuw et al. 2011).

\section{Inventory management and control}

The way inventory is portrayed in operations management literature shows a great deal of variation. At the most extreme end, the literature on lean production depicts inventory as muda (waste) (Bowerson et al. 2015; Womack \& Jones 1996). In this case, efforts are oriented towards minimising inventory in supply chains, partly because it is often viewed as an indicator of process capability (Lieberman \& Demeester 1999). Not only Forrester (1961) but also Galbraith (1973) showed that inventory does not need to have such a negative connotation. It is a buffer against uncertainty, which, if used wisely, can be advantageous.

According to Cachon and Olivares (2010), any textbook on inventory management identifies the influence of supply lead times on inventory targets. This follows Little's simple law, which in some ways is almost a tautology; however, it does describe an important driver of inventory in production systems with a set lead time (Little 1961).

Secondly, inventory theory also stipulates that stock levels are related to batch sizes. The larger the production batch size, the longer the interval between two production batches, and, therefore, more inventory is required to cover demand during the interval between two production batches. Higher production flexibility can decrease production switching times and thus facilitates decreased batch sizes, with a resultant decrease in stock levels (Silver, Pyke \& Peterson 2009). Batch sizes are also affected by 
product variety. More product variety requires more production switching, hence longer times between productions of a given product, resulting in the need for higher inventory (Cachon \& Olivares 2010). Volume discounts also impact batch sizes. That is, higher volume discounts typically encourage customers to buy in larger quantities and thus increased inventory is required (De Leeuw et al. 2011). These first two factors determine the 'cycle stock'. The third well-known factor relates to the 'buffer' or 'safety' stock component of inventory, which focuses on covering uncertainty. Davis (1993) argues that there are three types of uncertainty - supply uncertainty, internal process uncertainty and demand uncertainty, of which demand uncertainty has the most influence. Zipkin (2000) and Silver et al. (2009) show that it is necessary to buffer against demand uncertainty if a certain level of customer service is to be achieved. Similarly, De Leeuw et al. (2011) show that supply uncertainties lead to the need for extra inventory against unreliable replenishment timing.

Closely related to demand uncertainty is seasonality. Greater seasonality is expected to lead to higher inventory levels (Cachon \& Olivares 2010). When it is costly to change production in synchronisation with demand, seasonality in demand leads to a gradual build-up of inventory during the low selling season followed by a rapid decrease in inventory during the peak selling season. The next factor that affects the level of inventory relates to the target service levels for customer demand (Cachon \& Olivares 2010). For example, more inventory is required if customers require instantaneous gratification, compared to a situation where customers are willing to wait (Rishi 2010). Target service levels depend on circumstances. Customers buying high-margin products are more sensitive to stock-outs (Rumyantsev \& Netessine 2007). In addition, the inventory levels have been found to relate to the size of the company. Frazelle (2016) has shown that by combining inventory from different locations into one pool from which all demand is satisfied, inventory levels can be lower and give the same customer service. Bigger companies are better able to pool inventory. The traditionally accepted factor is that the variety of products supplied influences inventory levels. More product variety leads to more variable demand for each variety (Bowerson et al. 2015) and the need for more changeovers in production (Frazelle 2016). Both higher variability in demand and the need for more changeovers (equalling less productive time) will necessitate more inventory. Chen et al. (2005) argue that traditional factors influence the level of inventory, as does the fear of losing sales, the strategy of make to stock production or speculative considerations.

Despite considerable efforts in inventory reduction, which showed success in reducing overall raw material and WIP inventory in the USA, finished goods inventory has not decreased overall statistically (Gupta et al. 2017; Hendricks \& Singhal 2008). In fact, the inventory levels of finished goods have increased in the automotive industry (measured in terms of number of days sales) (Chen et al. 2005; Kiff 2011). Furthermore, there is no consistent view across industries, which implies that there are industry-specific factors influencing inventory levels as well. The evidence as to what determines these inventory levels is mixed. Several authors (Cachon \& Olivares 2010; Gaur, Fisher \& Raman 2005; Lai 2005; Rumyantsev \& Netessine 2007) point towards a strong relationship between inventory levels and determinants such as gross margins, demand uncertainty and lead times. Chen et al. (2005), on the contrary, argue that other aspects such as macro-economic conditions have an influence on inventory levels. Cachon and Olivares (2010) stipulate five causes as to why finished goods inventories may not have decreased to the extent WIP and raw materials stock have. The five causes that they stipulate can be summarised in the following sentences: The production function has more control over component or raw material inventory than over finished goods inventory, where the marketing function has significant influence while typically having little incentive to reduce inventories. Finished goods are used as a buffer against demand uncertainties and firms may not be willing to reduce such stock for fear of losing sales.

When concentrating on inventory costs, tied-up capital is an important factor. Cachon and Olivares (2010) stress that the tied-up capital affects the cash flow and solvency of a company. It also affects the potential returns that could be received from invested capital, should the company have used it in another way. If there is too much tied-up capital in inventory, it hinders the capital of a company in making other investments with that capital. Specifically, the total inventory costs consist of the inventory carrying cost and the cost of personnel, space used for offices and systems that are employed to manage inventory (Frazelle 2016). According to Christopher (2005), these costs could be more than $50 \%$ of the current assets of a company. It must be noted that many authors refer to inventory carrying costs when illustrating the total inventory costs (Cachon \& Olivares 2010; Rishi 2010). The difference is that when all the costs related to inventory are included in inventory carrying costs, their percentage of the total inventory is higher than if they are excluded (De Leeuw et al. 2011). However, this study investigates the influence of inventory sequencing on inventory control in an automotive assembly plant. It explores the suitability of inventory sequencing as an appropriate tool for inventory control.

\section{Hypothesis}

The study is based on the following assumption:

H1: The implementation of an inventory sequencing system leads to the improvement of inventory control in the automotive assembly organisation.

H1a: The implementation of an inventory sequencing system does not lead to the improvement in inventory control in the automotive assembly organisation.

The following are sub-hypothesis:

H2: An increase in production volumes improves inventory control in the automotive assembly organisation.

H2o: An increase in production volumes reduces the control of inventory in the automotive assembly organisation. 
H3: An increase in inventory costs improves inventory control in the automotive assembly organisation.

H3o: An increase in inventory costs reduces the control of inventory in the automotive assembly organisation.

H4: An increase in product damages leads to the improvement of inventory control in the automotive assembly organisation.

H4o: An increase in product damages leads to the reduction of inventory control in the automotive assembly organisation.

\section{Methodology}

The method for this research will be discussed under the following headings, namely: research design and approach, company that participated in the study, data collection, as well as measurement and data analysis.

\section{Research design and approach}

This study was quantitative in nature. It examines the relationship of inventory control as a dependent variable to production volumes, inventory costs and product damages. Bryman and Bell (2015) state that the quantitative approach involves the use of statistical procedures to analyse the collected data. Consequently, after the measurements of the relevant variable, the scores were transformed using statistical methods. In addition, the study adopted a panel data analysis. According to Curwin and Slater (2002), panel data analysis is the statistical analysis of data sets consisting of multiple observations on each sampling unit. It contains more degrees of freedom and less multi-collinearity than cross-sectional data, thus improving the efficiency of econometric estimates (Bryman \& Bell 2015). For this study, the pre- and post-inventory sequencing data that were collected over time from the automotive assembly organisation have been analysed using the regression model. The study was also conclusive in design. Conclusive studies are intended to provide information that is useful in decisionmaking (Yin 2008).

\section{Company that participated in the study}

A convenience sample from one large automotive assembly organisation situated within the eThekwini District Municipality, KwaZulu-Natal province, South Africa, was used. The company had adopted an inventory sequencing strategy in their assembly division and agreed to participate in the study. The division had 194 employees. It operates a three-shift system.

\section{Data collection}

The collection of data from a single company that participated in the study was carried out in two phases, that is, the collection of pre- and post-inventory sequencing results by a quality control team leader from the operational records of the assembly plant. The data for production volumes, inventory costs and product damages were kept on the System, Applications and Products (SAP) version 6.0 data management programme. The collection of such data over time provided a greater capacity for capturing the complexity of inventory sequencing changes than using the one group post-test design that involves the collection of only the postdata after the changes have been implemented, resulting in threats to internal validity (Bryman \& Bell 2015). The validation of data from the SAP programme was performed by the researcher. This was achieved by comparing data from SAP with the documented data kept on files for accuracy.

The pre-inventory sequencing results were quarterly data reflecting the company's performance over the 4-year period prior to inventory sequencing implementation. This includes data from the first quarter of 2010 to the final quarter of 2013. The post-inventory sequencing data reflect the company's performance for 4 years after the inventory sequencing method was implemented. This includes data from the first quarter of 2014 to the final quarter of 2017.

\section{Measurement and data analysis}

The company's quarterly time series data on the production volumes, inventory costs and product damages were used. The measurements were based on a total of 96 observations. According to Westland (2010), there is no rule regarding the minimum number of observations for a balanced data panel. However, 50 observations are acceptable but more than 100 is recommended (Bryman \& Bell 2015). The regression model used was of the ordinary least square (OLS) variety. The choice was influenced by data constraints. However, the model provided the statistical method that enabled the researcher to examine the relationship between the variables effectively. The OLS used was as follows:

Inventory control $=\mathrm{B}_{\mathrm{o}}+\mathrm{B}_{1}$ Production volumes $+\mathrm{B}_{2}$ Inventory Costs $+\mathrm{B}_{3}$ Product Damages,

where $B_{\mathrm{o}}$ is the constant and $B$ is the coefficient of the independent variables.

The above regression model identifies inventory control as a function for production volumes, inventory costs rate and product damages.

Data were analysed by using a statistical package for social sciences (SPSS) version 25. It enabled the inventory sequencing data that were obtained, quarterly, over the multiple period time from the same operational division, to be appropriately analysed. Hence, the results provided unbiased estimations (Yin 2008). Furthermore, the OLS was based on the fixed-effect model. The fixed effect is a statistical model in which the model parameters are fixed (i.e. nonrandom quantities) (Curwin \& Slater 2002). Consequently, the variables were collected, quarterly, from the first quarter of 2010 to the last quarter of 2017 from the same company. For this study to achieve its objectives, the normality test was conducted using Kolmogorov-Smirnov and Shapiro-Wilk's tests for the overall score of the constructs. Table 1 presents 
results for normality tests for production volumes, inventory costs and product damages.

Statistical tests show that the data were not normally distributed $(p>0.05)$. Hence, the study results were analysed using non-parametric tests, that is, the $t$-tests.

\section{Ethical consideration}

The researcher complied to the process of data confidentiality and informed consent. The respondents were not asked to perform any acts or make statements that might be expected to cause discomfort. The researcher did not expect to obtain any direct or indirect financial or other benefits from conducting the research.

\section{Study results}

This section presents results for the pre- and post-inventory sequencing means variable comparison and inventory control.

\section{Pre- and post-inventory sequencing means variable comparisons}

Table 2 compares the means (in percentages) for production volumes, inventory costs and product damages.

Table 2 indicates that the percentage mean data for preinventory sequencing for product volumes, inventory costs and product damages were $40.31 \%, 43.75 \%$ and $48.44 \%$, respectively. However, the percentage mean data of postinventory sequencing for production volumes, inventory costs and product damages were $33.0 \%, 22.50 \%$ and $22.56 \%$, respectively. The results show a decrease in mean values on all three variables (i.e. the production volumes, inventory costs and product damages) when post-inventory sequencing is compared with the pre-inventory sequencing periods. This indicates the effect of inventory sequencing system on inventory control.

TABLE 1: Normality tests for production volumes, inventory costs and product damages.

\begin{tabular}{|c|c|c|c|c|c|c|c|}
\hline \multirow[t]{2}{*}{ Variable } & \multicolumn{4}{|c|}{ Kolmogorov-Smirnov $\dagger$} & \multicolumn{3}{|c|}{ Shapiro-Wilk } \\
\hline & Group & Statistic & df & Sig. & Statistic & df & Sig. \\
\hline \multirow[t]{2}{*}{ Production volumes } & 0 & 0.117 & 16 & $0.200^{*}$ & 0.981 & 16 & 0.971 \\
\hline & 1 & 0.173 & 16 & $0.200^{*}$ & 0.942 & 16 & 0.381 \\
\hline \multirow[t]{2}{*}{ Inventory costs } & 0 & 0.110 & 16 & $0.200 *$ & 0.954 & 16 & 0.551 \\
\hline & 1 & 0.152 & 16 & $0.200 *$ & 0.967 & 16 & 0.786 \\
\hline \multirow[t]{2}{*}{ Product damages } & 0 & 0.242 & 16 & 0.013 & 0.902 & 16 & 0.086 \\
\hline & 1 & 0.187 & 16 & 0.139 & 0.926 & 16 & 0.214 \\
\hline
\end{tabular}

df, degrees of freedom; Sig., significance.

*, This is a lower bound of the true significance.

$\dagger$, Lilliefors significance correction.

TABLE 2: Pre- and post-inventory sequencing percentage means variable comparisons.

\begin{tabular}{llccc}
\hline No. & Variable & $\begin{array}{c}\text { Pre-inventory } \\
\text { sequencing } \\
\text { period (\%) }\end{array}$ & $\begin{array}{c}\text { Post-inventory } \\
\text { sequencing } \\
\text { period (\%) }\end{array}$ & $\begin{array}{c}\text { Percentage mean } \\
\text { difference } \\
\text { (pre-post) }\end{array}$ \\
\hline 1. & Production volumes & 40.31 & 33.00 & +7.31 \\
2. & Inventory costs & 43.75 & 22.50 & +21.25 \\
3. & Product damages & 48.44 & 22.56 & +25.88 \\
\hline
\end{tabular}

\section{Inventory control results}

Table 3 presents the results for inventory control as a dependent variable to production volumes, inventory costs and product damages.

\section{Inventory control as a dependent variable to production volumes}

The results show that the production volumes have no relationship with the control of inventory in the automotive assembly organisation. This is determined by its $t$-value of 0.186 as well as the $p$-value of 0.854 . The $t$-value is below the critical value of 1.960 at the $5 \%$ level of significance (Curwin \& Slater 2002) and the $p$-value is above the 0.05 level. Thus, the null hypothesis that there is no relationship between these two variables is acceptable. Consequently, Chen et al. (2005) present the traditional factors that influence inventory control. These include the fear of losing sales and the strategy for manufacturing to stock production.

\section{Inventory control as a dependent variable to inventory costs}

Results as illustrated in Table 3 show that inventory costs have no relationship with inventory control in the automotive assembly organisation. This is determined by its $t$-value of -0.293 as well as the $p$-value of 0.771 . The $t$-value is below the critical value of 1.960 at the $5 \%$ level of significance and the $p$-value is above the 0.05 level. The null hypothesis that there is no relationship between these two variables is acceptable. Similarly, Gupta et al. (2017) indicates that the use of a more efficient assembly line technique influences the control of inventory. This allows the production of an automobile to be manufactured and sold at a reasonable cost.

\section{Inventory control as a dependent variable to product damages}

Results show that product damages have a relationship and are statistically significant with inventory control as shown by its $t$-value of -2.987 and the $p$-value of 0.006 . The $t$-value is above the critical value of 1.960 at the $5 \%$ level of significance (Curwin \& Slater 2002) and the $p$-value is below the 0.05 level. The negative relationship indicates that any decrease in product damages would result in an increase in inventory control. It has the adjusted $R^{2}$ of 0.541 , which implies that product damages account for approximately 54\% of the variance in inventory control. Furthermore, the serial correlation is also low at 0.709 when compared to the standard value of 1.73 at the $5 \%$ level of significance (Curwin \& Slater 2002). According to Mattsson (2007), inventory is considered

TABLE 3: Inventory control results relating to production volumes, inventory costs and product damages.

\begin{tabular}{lccc}
\hline Regression & Coefficient & $\boldsymbol{t}$-statistic & Probability \\
\hline Constant $\left(B_{0}\right)$ & 1.286 & 6.625 & 0.000 \\
Production volumes & 0.025 & 0.186 & 0.854 \\
Inventory costs & -0.072 & -0.293 & 0.771 \\
Product damages & -0.712 & -2.987 & 0.006 \\
$R$-squared & 0.585 & $F$-statistics & 13.160 \\
Adjusted $R^{2}$ & 0.541 & Sum of squares & 4.680 \\
Standard error of regression & 0.344 & Durbin-Watson stat. & 0.709 \\
\hline
\end{tabular}

Note: Regression data: 2010-2017 for 96 observations. 
to be a waste as it is tied up to capital. Any damage on a product has a negative impact on cash flow. Thus, companies typically spend heavily on inventory management control.

\section{Summary of results: Statistical tests and box plots}

This section analyses data by using factorial designs. It incorporates box plots to determine whether the factorial Analysis of Variance (ANOVA) assumptions of normality and homogeneity of variances have been met. Porkess (2005) explains that the populations represented should be normally distributed (i.e. the normality), making the mean an appropriate measure of central tendency. However, the homogeneity of variances indicates that the population from which the data are sampled should have the same variance.

The Bartlett's test was used to verify whether the variances were equal for all the samples (Curwin \& Slater 2002). Figure 1 presents a summary of the results from the Bartlett's test for homogeneity of variances.

Table 4 presents detailed results of Bartlett's test for homogeneity of variances for production volumes, inventory costs and product damages.

The $p$-value in the Bartlett's test (at $p>0.05$ ) shows that the homogeneity of variances is violated. The $p$-value at 0.329 is above the significant level of 0.05 . Therefore, the variances are not equal, given the amount of variability in the variances that can naturally occur in the data. The results are confirmed by box plots in Figure 2.

Figure 2 shows that the mode of change from the pre- to postinventory sequencing period is homogeneous. However, the box plots indicate that the variances for production volumes, inventory costs and product damages are not equal. This was confirmed by Bartlett's test results. This shows an influence of the inventory sequencing system on inventory control in the automotive assembly organisation that participated in the study.

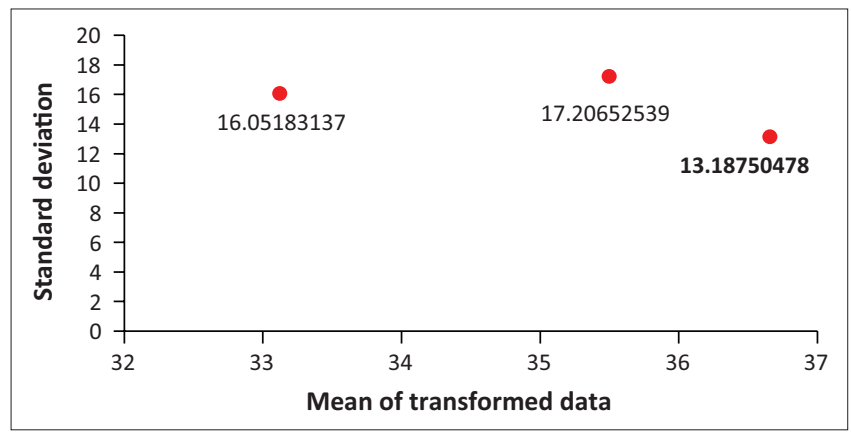

FIGURE 1: Bartlett's test for homogeneity of variances.

TABLE 4: Bartlett's test for homogeneity of variances.

\begin{tabular}{lccc}
\hline Variables & $\begin{array}{c}\text { Means of } \\
\text { transformed data }\end{array}$ & $\begin{array}{c}\text { Standard deviations of } \\
\text { transformed data }\end{array}$ & $\boldsymbol{p}$ \\
\hline Production volumes & 36.657 & 13.188 & 0.329 \\
Inventory costs & 33.125 & 16.052 & \\
Product damages & 35.500 & 17.207 & \\
\hline
\end{tabular}

\section{Discussion}

The study investigates the influence of inventory sequencing for the improvement of inventory control in the automotive assembly organisation that participated in this research. It revealed that the inventory control in the supply chain is one of the major challenges in business. The traditional supply chain consisted of a sequence of weakly connected activities both within and outside the organisation and leads to many misalignments (Holweg \& Pil 2014). A major value creation opportunity for managers would be to resolve this inherent lack of coordination and control (Lee \& Billington 2014). Hence, the study examined the production and related experiences of the automotive assembly organisation that has adopted an inventory sequencing strategy within its processes. Quarterly time series data on production volumes, inventory costs and product damages were used to analyse data. The study indicates that both the production volumes and the inventory costs have no relationship with the inventory control in the automotive assembly organisation. However, product damages have a relationship with inventory control. Consequently, Lee-Mortimer (2006) indicates that process improvement techniques contribute to inventory reduction and product damages. The inventory reduction is identified as a benefit of implementing JIT (Salaheldin 2005).

\section{Implications of results for policy and practice}

The assembly plant of the automotive industry should revise their operations management systems and develop inventory control strategies, policies and practices that help to achieve new business goals and support organisational and cultural change (De Leeuw et al. 2011). This must be based on an understanding of the economic factors affecting inventory as a directory that provides enough products for meeting customer demand levels (Frazelle 2016), the management of inventory in the supply chain (Bowerson et al. 2015; Holweg \& Pil 2014) and the inventory costs (Cachon and Olivares 2010; De Leeuw et al. 2011). Besides the achievement of study objectives, the following conclusions can be made on inventory sequencing philosophy:

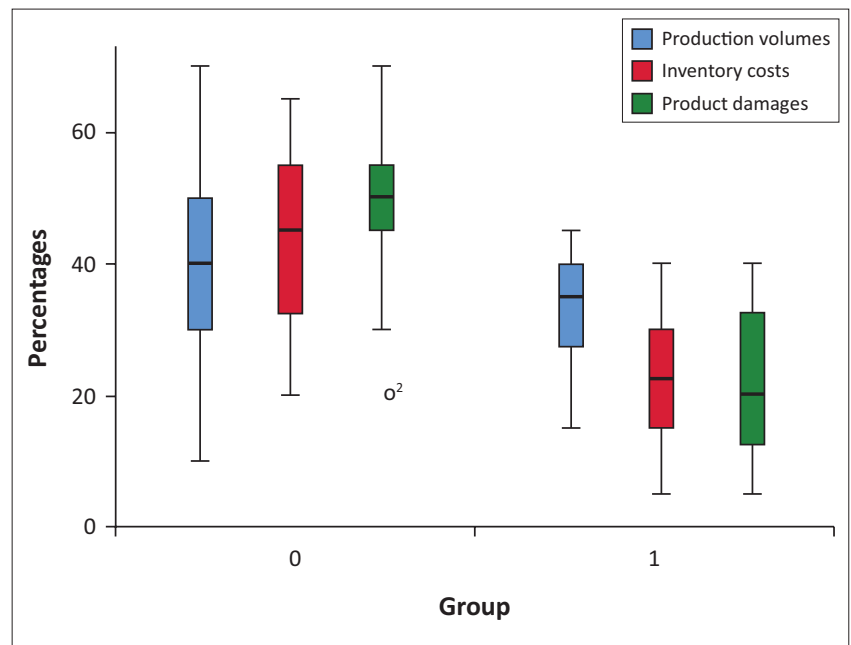

FIGURE 2: Box plots determining the normality and homogeneity of variances. 
- Inventory management ensures that service commitments for customers are met (Bowerson et al. 2015).

- To maximise performance, a comprehensive Operations Management (OM) policy must be developed, which aligns inventory sequencing to productivity (De Leeuw et al. 2011).

\section{Study limitations}

The study was limited to an automotive assembly plant within the eThekwini District Municipality. The investigation was conducted in a single company that has adopted an inventory sequencing system. As there are 22 registered assembly plants in South Africa (SAinfo 2018), the results cannot be extrapolated to other companies within the sector. Secondly, it did not examine the process followed during the inventory sequencing, including (amongst others) the individuals who participated in the implementation process. It only used quarterly time series data to determine the pre- and post-material productivity effects resulting from inventory sequencing strategy. Lastly, the econometrics model used was of the OLS variety, solely because of data constraints. Future studies ought to use the more advanced Johansen Vector Auto Regression(VAR) methodology or panel data analysis, both of which rely on large data sets.

\section{Conclusion}

The inventory management theory is concerned with defining minimal inventory levels, given certain exogenous variables such as supply and delivery lead time (LT), supply and demand uncertainty, batch sizes and product variety (Rumyantsev \& Netessine 2007). Thus, the control of inventory is an important function in maintaining the right balance of stock in both the production process and the warehouse (Kiff 2011). The goal of inventory control is to generate the maximum profit from the least amount of inventory investment without intruding upon customer satisfaction levels (Rishi 2010). Hence, inventory remains a directory that provides enough products in order to meet customer demand levels (Frazelle 2016). The inventory sequencing system that is properly implemented and managed results in an improvement in inventory control.

\section{Future research required}

During the course of this study, issues relating to the longterm survival of an inventory sequencing strategy after implementation were not covered. This includes the applicability of an inventory sequencing strategy to a wider sector of economic activity, including the public sector. The nature of this research did not allow these areas to be covered in depth. It is recommended that future research should examine the following issues in greater depth:

- when to use and when not to use an inventory sequencing system

- the applicability of an inventory sequencing approach to other industrial sectors

- the process followed during the implementation of an inventory sequencing system
- a more comprehensive investigation should be carried out using a randomised sample of the registered automotive manufacturers that use an inventory sequencing strategy, to see if the results can be generalised.

The study investigated the influence of inventory sequencing for the control of inventory in the automotive assembly organisation in South Africa. The pre- and post-inventory sequencing quarterly data from company records were collected. The study established that the inventory sequencing has no influence on either the production volumes or the inventory costs. However, it has the ability to reduce product damages.

\section{Acknowledgements Competing interests}

The author declares that he has no financial or personal relationships that may have inappropriately influenced him in writing this article.

\section{Author's contributions}

I declare that I am the sole author of this article.

\section{Funding information}

The article fee was paid by the researcher fund kept by the Durban University of Technology.

\section{Data availability statement}

Data sharing is not applicable to this article as no new data were created or analysed in this study.

\section{Disclaimer}

The views and opinions expressed in this article are those of the authors and do not necessarily reflect the official policy or position of any affiliated agency of the authors.

\section{References}

Bhasin, S., 2008, 'Lean and performance measurement', Journal of Manufacturing Technology Management 19(5), 670-684. https://doi.org/10.1108/174103808 10877311

Bowerson, D.J., Closs, D.J. \& Cooper, M.B., 2015, Supply chain logistics management, McGraw-Hill, New York.

Bryman, A. \& Bell, E., 2015, Business research methods, Oxford Press, Oxford, UK.

Cachon, G.P. \& Olivares, M., 2010, 'Drivers of finished-goods inventory in the US automobile industry', Management Science 56(1), 202-216. https://doi.org/ 10.1287/mnsc.1090.1095

Chen, H., Frank, M.Z. \& Wu, O.Q., 2005, 'What actually happened to the inventories of American companies between 1981 and 2000?', Management Science 51(7), 1015-1031. https://doi.org/10.1287/mnsc.1050.0368

Christopher, M., 2005, Logistics and supply chain management: Creating value-adding networks, Pearson Education Limited, Harlow.

Curwin, J. \& Slater, R., 2002, Quantitative methods for business decisions, British Library Cataloguing Data, London.

Davis, T., 1993, 'Effective supply chain management', Sloan Management Review 34(4), 35-46.

De Leeuw, S., Holweg, M. \& Williams, G., 2011, 'The impact of decentralised control on firm level inventory: Evidence from the automotive industry', International Journal of Physical Distribution \& Logistics Management 41(5), 435-456, https:// doi.org/10.1108/09600031111138817 
Demeter, K. \& Matyusz, Z., 2011, 'The impact of lean practices on inventory turnover' International Journal of Production Economics 133(1), 154-163. https://doi.org/ International Journal of Produ

Dubelaar, C., Chow, G. \& Larson, P.D., 2001, 'Relationships between inventory, sales and service in a retail chain store operation', International Journal of Physical Distribution and Logistics Management 31(2), 96-108. https://doi.org/10.1108/ 09600030110387480

Drucker, P., 1946, The concept of the corporation, John Day, New York.

Forrester, J.W., 1961, Industrial dynamics, MIT Press, Cambridge, MA.

Frazelle, E., 2016, Supply chain strategy: The logistics of supply chain management, McGraw-Hill, New York.

Galbraith, J., 1973, Designing complex organisations, Addison-Wesley, Reading, MA.

Gaur, V., Fisher, M.L. \& Raman, A., 2005, 'An econometric analysis of inventory turnover performance in retail services', Management Science 51(2), 181-194. https://doi.org/10.1287/mnsc.1040.0298

Grünwald, H.J. \& Fortuin, L., 2013, 'Many steps towards zero inventory', European Journal of Operational Research 59(3), 359-369. https://doi.org/10.1016/03772217(92)90193-D

Gupta, S., Vanajakumari M. \& Sriskandarajah, C., 2017, 'Sequencing deliveries to minimize inventory holding cost with dominant upstream supply chain partner', Journal of Systems Science Engineering 18(2), 159-183. https://doi.org/10.1007/ s11518-009-5107-0

Heizer, J. \& Render, B., 2011, Operations management, 10th edn., Prentice Hall, Boston, MA.

Helper, S.R. \& Sako, M., 2009, 'Supplier relations and performance in Europe, Japan and the US: The effect of the voice/exit choice', in Y. Lung, J.J. Chanaron, T. Fujimoto \& D.M.G. Raff (eds.), Coping with variety: Product variety and productive organisations in the world automotive industry, Ashgate, Aldershot.

Hendricks, K.B. \& Singhal, V.R., 2008, Demand-supply mismatch and stock market reaction: Evidence from excess inventory announcements, Working paper, Georgia reaction: Evidence from excess inventory
Institute of Technology, Atlanta, GA.

Holweg, M. \& Pil, F.K., 2014, The second century: Reconnecting customer and value chain through build-to-order, vol. xi, p. 238, MIT Press, Cambridge, MA.

Karlsson, C. \& Ahlstrom, P., 1996, 'Assessing changes towards lean production', International Journal of Operations \& Production Management 16(2), 24-41. https://doi.org/10.1108/01443579610109820

Kiff, J.S., 2011, 'Supply and stocking systems in the UK car market', Internationa Journal of Physical Distribution \& Logistics Management 27(3/4), 226-243. https://doi.org/10.1108/09600039710170593

Lai, R., 2005, Inventory signals, Working paper, Harvard NOM, Cambridge, MA.

Lee, H.L. \& Billington, C., 2014, 'Material management in decentralized supply chains', Operations Research 41(5), 835-847. https://doi.org/10.1287/opre.41.5.835

Lee-Mortimer, A., 2006, 'A lean route to manufacturing survival', Assembly Automation 26(4), 265-272. https://doi.org/10.1108/01445150610705155

Lieberman, M.B. \& Demeester, L., 1999, 'Inventory reduction and productivity growth: Linkages in the Japanese automotive industry', Management Science 45(4), 466-485. https://doi.org/10.1287/mnsc.45.4.466

Liker, J. \& Wu, Y.C., 2000, 'Japanese automakers, US suppliers and supply-chain superiority', Sloan Management Review 42(1), 81-93.
Little, J.D.C., 1961, 'A proof of the queuing formula $L=\lambda W$ ', Operations Research 9(3), 383-387. https://doi.org/10.1287/opre.9.3.383

MacDuffie, J.P., Sethuraman, K. \& Fisher, M.L., 2009, 'Product variety and manufacturing performance: Evidence from the international automotive assembly plant study', Management Science 42(3), 350-369. https://doi.org/10.1287/mnsc.42.3.350

Martínez-Sánchez, A. \& Pérez-Pérez, M., 2001, 'Lean indicators and manufacturing strategies', International Journal of Operations \& Production Management 21(11), 1433-1452. https://doi.org/10.1108/01443570110407436

Mattsson, S., 2007, 'Inventory control in environments with short lead times', International Journal of Physical Distribution \& Logistics Management 37(2), 115-130. https://doi.org/10.1108/09600030710734839

Monden, Y., 1983, The Toyota production system, Productivity Press, Portland, OR.

Motwani, J., 2003, 'A business process change framework for examining lean manufacturing: A case study', Industrial Management \& Data Systems 103(5), 339-346. https://doi.org/10.1108/02635570310477398

Porkess, R., 2005, Collins internet-linked dictionary of statistics, HarperCollins, Glasgow.

Raturi, A.S., Meredith, J., McCutheon, D. \& Camm, J., 2011, 'Coping with the build-toforecast environment', Journal of Operations Management 9(2), 230-249. https://doi.org/10.1016/0272-6963(90)90097-W

Rishi, G., 2010, 'Tracking the trends in inventory management in the automobile manufacturing industry throughout the business cycle', Honors Scholar thesis,
p. 137, reviewed 23 November 2018 , from https://opencommons.uconn.edu/ p. 137 , reviewed 23
srhonors_theses/137.

Rumyantsev, S. \& Netessine, S., 2007, 'What can be learned from classical inventory models? A cross-industry exploratory investigation', Manufacturing \& Service models? A cross-industry exploratory investigation, Manufacturing \& Service
Operations Management 9(4), 409-429. https://doi.org/10.1287/msom.1070.0166

SAinfo, 2018, South Africa's automotive industry, viewed 23 September 2019, from http://www.southafrica.info/doing_business/economy/key_sectors/ motorindustryboost.html.

Salaheldin, I.S., 2005, 'JIT implementation in Egyptian manufacturing firms: Some empirical evidence', International Journal of Operations \& Production Management 25(4), 354-370. https://doi.org/10.1108/01443570510585543

Schonberger, R.J., 1982, Japanese manufacturing techniques, The Free Press, New York.

Silver, E., Pyke, D. \& Peterson, R., 2009, Inventory management and production planning and scheduling, Wiley, New York.

Uddin, M.K., Soto, M.C. \& Lastra, J.L.M., 2010, 'An integrated approach to mixed model assembly line balancing and sequencing', Assembly Automation 30(2), 164-172. https://doi.org/10.1108/01445151011029808

Westland, J.C., 2010, 'Lower bounds on sample size in structural equation modelling', Electronic Commerce Research and Applications 9(6), 476-487. https://doi.org/ 10.1016/j.elerap.2010.07.003

Womack, J.P. \& Jones, D.T., 1996, Lean thinking, Simon \& Schuster, London.

Womack, J.P., Jones, D.T. \& Roos, D., 2012, The machine that changed the world, Rawson Associates, New York.

Yin, R.K., 2008, Handbook of applied research, Sage, Thousand Oaks, CA.

Zipkin, P.H., 2000, Foundations of inventory management, McGraw-Hill, Boston, MA. 